\title{
Gamification for Science Learning Media: Challenges of Teacher and Expectations of Students
}

\author{
https://doi.org/10.3991/ijim.v15i01.15175
}

\author{
Achmad Lutfi (ه), Rusly Hidayah \\ Universitas Negeri Surabaya, Surabaya, Indonesia \\ achmadlutfi@unesa.ac.id
}

\begin{abstract}
The purpose of this research was to determine the response of teachers and students towards the use of computer-based games as medium for learning sciences. Data was collected from students in two classes of grade nine junior high school in Surabaya, East Java, Indonesia, through observation, questionnaire, and interviews. Science learning using games media was performed on atomic subjects by respective science teachers. Additional worksheets were also given to be used by students. Results showed that $87.50 \%$ to $100 \%$ of students supported the use of computer-based games as science learning media to achieve specified target. Based on statistical test, significant difference was found between pretest and posttest scores. On the other hand, teachers believed that the use of gamification was very good because it enabled students to play while learning. Therefore, it had the ability to prevent them from participating in less educational games. The use of computerized games as science learning media was highly accepted due to its ability to increase student's learning activities, complied to target of classical completeness. Hence, teachers need to have a thorough understanding of ways to operate the game on computer, as effort to improve science learning.
\end{abstract}

Keywords-Teacher responses, students' expectation, gamification, learning science

\section{Introduction}

Recent development of learning technologies and methodologies supports emergence of new opportunities in education; however, it is also become a challenge for teachers. This is because they need to decide whether to apply it or not based on expected outcomes, performance, costs, and benefits. The cost of implementing new learning technologies in the classroom, the availability of personal and institutional costs, as well as the time devoted to preparing new lessons need to be considered carefully. In addition, teacher's response to expected outcomes and students' satisfaction towards implementation of new learning strategies also affects the decision [3]. Presently, the advancement of technology and information has changed models and patterns of learning worldwide. An example of application of technology for learning is the use of computer-assisted game for science learning [2]. 
Based on interview with two science teachers at two different junior high schools in Surabaya, East Java - Indonesia, students had low-level learning process of $56 \%$ to $69 \%$ in studying atomic materials, which increased before remedial. This means that the ability of students was still below the standard limit of 75 . Several factors cause these conditions were lack of motivation to learn, students prefer playing games on laptop, lack of visualization in learning science, educators tend to be passive or less active, and feeling of boredom [14]. Students with lack of motivation tended to ignore learning process and did not compelled to get the best result to improve their knowledge. Limited number of face-to-face meetings, lack of supporting facilities to teach science, particularly in atomic material, and the demand to use learning media able to visualize the concept of atoms cause teachers to not be able to achieve expected targets. Therefore, a follow-up effort is needed to solve these issues. Teacher can use several types of learning medium to improve science learning. Computerassisted game can be applied to make science learning more interesting and effective for students.

Junior high school students are categorized within the age group of children who are always eager to play [16]. This is a challenge for teachers as only a few games can serve as medium for learning science. Teacher should have thorough understanding of game operations both on computer and smartphone to choose the right game that will be used to as a learning medium in science learning.

Based on initial interview, the highest frequency of student playing hours was at everyday (32.32 - 34.4\%), followed by sometimes (26.26-26.88\%), and the least was every month $(16.12-16.16 \%)$. According to the data, almost all the students enjoyed playing games and spent a lot of times using their laptop or smartphone. Therefore, there is a great opportunity for them to learn science using games on their laptop or smartphone.

Games can be used as tools to motivate students for them to achieve maximum learning completeness. This is due to the fact that motivation is an important factor in the learning process, which is positively correlates to students' willingness to learn, as well as their level of cognition, creativity, and performance [5]. The more varied media used, the more optimal the message received by students, and this in turn tends to improve learning outcomes [21]. Variation and diversity of student learning modalities are accommodated by various media applied. Furthermore, computerbased games tend to trigger an effective learning process. According to previous study, games serve as learning medium that is able to increase students' internal motivation $[17,19]$. It can also serve as means of cognitive learning due to several factors, such as increasing interest, motivation, ability to remember, and high-level thinking capabilities, which affect learning outcomes [13].

Games as a learning medium helps students to study independently and create recreational atmosphere able to increase learning motivation. In accord to several previous studies on gamification, by motivating students through gift-based learning methods, their skills could be increased [1].

By using games, students did not quickly feel bored or burdened by learning chemistry with real examples that were difficult to remember. Each level in the game usually had gradual stages of difficulty. Curiosity was also raised due to students 
wanted to finish the game. In the end, there was score achieved by players, in addition to direct feedback which had good effect on students [18]. Students will try continuously to finish the game and achieve high score. Thus, they can learn the materials indirectly.

Gamification raises enthusiasm of students to explore a given material further. It has also been proven to offer quality progress. By using games as learning media, learning become a dynamic and interesting activity, in addition of increasing effectiveness [8]. Playing has been reported to facilitate learning outcomes in science [7]. Furthermore, games are believed to have potential to facilitate cognitive and affective learning processes.

The ability of educational games to boost learning success can possibly be applied to science learning. Based on the description above, it was necessary to study responses of teachers and expectations of students in regard of the use and effect of computer-based games as media for learning atomic material.

\section{$2 \quad$ Method of Research}

This research was conducted on students in two different classes of grade nine in different Junior High Schools located at Surabaya, East Java, Indonesia. The classes were determined randomly, while determination of schools were based on its accreditation status. Preliminary tests were conducted before the employment of computerized game as learning medium. Additionally, all activity of teacher and student was observed during learning process. After the final tests, questionnaires were given to students and teachers interviewed. The study was conducted during even semester of 2018/2019 in both schools. Computer-based games as science learning media has been previously validated [9].

\subsection{Teacher activity}

Activity of teachers was observed to obtain general picture of computer-based game implementation designed as science learning media. Observation were performed based on implementation percentage of learning plan at opening, core, and closing stages.

\subsection{Student activities}

Observation sheets were arranged to obtain general picture of students' activities during learning process. Activities observed included asking questions (AQ), offering input to the problem being presented (PP), discovering new things (FN), trying challenging tasks (TCT), explaining answers found to other friends (DA), presenting in front of the class (WC), questioning the work of teacher or students comparing it with their own answers (QR). In addition to mentioned activities, observations also included data concerning computer-game skills of students. Student activity data was analyzed descriptively. Activities observed were categorized into five levels; very 
often, often, quite often, rarely, and never. Assessment for activity frequency of students used scale as presented in Table 1. Assessment result was then further categorized based on activity categorization on Table 2 .

Table 1. Student activity assessment scale

\begin{tabular}{|l|c|l|}
\hline \multicolumn{1}{|c|}{ Frequency (f) } & Score & \multicolumn{1}{c|}{ Category } \\
\hline $\mathrm{f}<2$ & 0 & Never appear \\
\hline $2 \leq \mathrm{f}<3$ & 1 & Rarely appear \\
\hline $3 \leq \mathrm{f}<5$ & 2 & Slightly often appear \\
\hline $5 \leq \mathrm{f}<8$ & 3 & Often appear \\
\hline $\mathrm{f} \geq 8$ & 4 & Very often appear \\
\hline
\end{tabular}

Table 2. Activity category

\begin{tabular}{|l|l|}
\hline \multicolumn{1}{|c|}{ Average of Activity } & \multicolumn{1}{c|}{ Category } \\
\hline Average $>3,20$ & Very often \\
\hline $2,40<$ Average $\leq 3,20$ & Often \\
\hline $1,60<$ Average $\leq 2,40$ & Slightly Often \\
\hline $0,80<$ Average $\leq 1,60$ & Rarely \\
\hline Average $\leq 0,80$ & Never \\
\hline
\end{tabular}

\subsection{Student questionnaire}

The questionnaire was designed to obtain responses and attitudes of students towards learning process using games as science learning media. If a student answered "yes" on positive statements, they were scored 1. In opposite, when their answer was "no", then the score was 0 . Similarly, answer "no" on negative statements would be scored 1 and vice versa. Response of students obtained from the questionnaire was evaluated as percentage.

\subsection{Student interviews}

Interview was conducted to support or clarify answers in student's questionnaires. It was performed after learning process, with each group consisted of 3-4 students.

\subsection{Teacher questionnaire}

Questionnaire for teachers was conducted after media implementation. Expected objectives of the questionnaire were (1) response of teacher to the employment of games as science learning media, (2) assessment of teacher to the tool used in implementing learning, and (3) expectation of teacher from the use of games as media. 


\subsection{Teacher interview}

Interview with teacher was conducted to clarify answers in the questionnaire. Results from questionnaires and interviews were analyze descriptively.

\subsection{Student learning outcomes}

Instruments were composed according to learning objectives as multiple-choice questions. Learning outcomes tests were conducted before (pretest) and after learning (posttest) to determine effect of games as learning media. The success of students was determined by score obtained in class, classical completeness, as well as difference of posttest and pretest scores. Challenges encountered by the teachers were evaluated based on their willingness to use games as learning media and participate in innovative training. Expectations of students were evaluated based on their interest and desire to learn science with the application of games as learning media, its effect was subsequently evaluated in accord to their activities during learning and the outcomes.

\section{Results and Discussion}

\subsection{Teacher activity}

Evaluation of teacher activities showed that almost all learning plans $(85.0 \%$ $98.5 \%$ ) were conducted (Table 3). These showed that the use of games as learning media for studying Atoms achieved excellent results.

Table 3. Observation results on teacher activity

\begin{tabular}{|c|l|c|c|}
\hline No & \multicolumn{1}{|c|}{ Activity } & Class A (\%) & Class B (\%) \\
\hline 1 & Learning Opening & 98.5 & 97.5 \\
\hline 2 & Learning Core & 95.5 & 94.0 \\
\hline 3 & Learning Closing & 85.0 & 88.0 \\
\hline
\end{tabular}

Learning was carried out in accordance to steps in the learning plan (Table 3). It was discovered that learning closing activity had lowest percentage compared to opening and core. This was because at the end of the learning process, students seemed to be more interested and focused on the game, making it difficult for teacher to convey necessary instructions at the end of lesson. Students continued to play and learn despite the need to complete lesson plan. Game has its own advantages compared to other media because it makes learning more interesting, exciting, and less monotonous [10]. 


\subsection{Student activity}

Observation conducted during learning in classes A and B was aimed to obtain data on activities of students. Results from the observation performed by two observers in classes are presented in Table 4.

Table 4. Observation results of student activities

\begin{tabular}{|l|c|c|c|c|}
\hline \multirow{2}{*}{ Activity } & \multicolumn{2}{c|}{ Class A } & \multicolumn{2}{c|}{ Class B } \\
\cline { 2 - 5 } & Obs. 1 & Obs. 2 & Obs. 1 & Obs. 2 \\
\hline AQ & 4 & 5 & 5 & 4 \\
\hline PP & 3 & 2 & 3 & 3 \\
\hline FN & 4 & 4 & 3 & 4 \\
\hline TCT & 3 & 2 & 3 & 3 \\
\hline DA & 3 & 2 & 3 & 2 \\
\hline WC & 2 & 3 & 3 & 2 \\
\hline QR & 2 & 2 & 3 & 2 \\
\hline Total & 21 & 20 & 22 & 20 \\
\hline Mean & \multicolumn{2}{|c|}{2.92} & & 3.00 \\
\hline
\end{tabular}

Mean observations of the student activities in classes A and B were found to be 2.92 and 3.00, which could be categorized or reported as student-centered learning. Based on results, the activity of asking questions (AQ) was high (4), which means that games tended to encourage students to ask questions. However, result also showed that the activity of questioning the work of teachers or students comparing it with their own answers (QR) was still low. This result was in accordance with previous research which reported that when the game was used appropriately, it could relieve stress in learning environment [15], inspire students to be fully involved, and increase their enthusiasm during learning process [19]. Interactive games consisted of educational materials can increase interest and awareness of students for educational process [20].

\subsection{Student's questionnaire}

The questionnaire was given to students after learning process. The results from the questionnaires distributed in classes A and B with a total of 32 and 33 students respectively, are shown in Table 5. 
Table 5. Answers in Student Questionnaire

\begin{tabular}{|c|l|c|c|c|c|}
\hline \multirow{2}{*}{ No } & \multicolumn{1}{|c|}{ Statement } & \multicolumn{2}{c|}{ Answer of Class A } & \multicolumn{2}{c|}{ Answer of Class B } \\
\cline { 3 - 6 } & & Score & \% & Score & \% \\
\hline 1 & $\begin{array}{l}\text { After learning science with the game, I developed } \\
\text { interest in science }\end{array}$ & 30 & 93.75 & 31 & 93.93 \\
\hline 2 & I need to study science again with games & 30 & 93.75 & 33 & 100.00 \\
\hline 3 & I felt that learning science by playing made it easier & 29 & 90.62 & 29 & 87.87 \\
\hline 4 & If allowed, I want to use the game to study at home & 28 & 87.50 & 30 & 90.90 \\
\hline 5 & I desire to tell a friend or parent about learning science & 29 & 90.62 & 31 & 93.93 \\
\hline $6^{*}$ & I felt that the duration for learning science was lengthy & 31 & 96.88 & 31 & 93.93 \\
\hline $7^{*}$ & I believed that learning science by playing was boring. & 30 & 93.76 & 30 & 90.90 \\
\hline $8^{*}$ & $\begin{array}{l}\text { I want the learning of science with the implementation } \\
\text { of games to be stopped }\end{array}$ & 32 & 100.00 & 31 & 93.93 \\
\hline
\end{tabular}

*Negative statement

Result of questionnaire for students showed that scores from classes A and B were $87.50 \%-100 \%$ and $87.87 \%$ - $100 \%$ respectively. It means that generally students supported the use of computerized games as media for learning atoms. One of the supporting agreements was the desire of students to always want to study with the game and the desire to continue learning even when lesson time was up. It meant that students want to continue to learn using games. This result was in accordance with previous study in which computer-based educational games could make students excited, and students tended to enjoy the learning process [11]. Therefore, students were motivated and wanted to continue learning. The results of the questionnaire showed that each statement had surpassed standard limit of positive attitude $(\geq 75 \%)$ determined by using games as a learning media. It means that students supported the use of computerized games as science learning media, and they wish that it can be maintained.

\subsection{Teacher's questionnaire}

Answer to questionnaire distributed to the two science teachers is shown in Table 6. The questionnaire distributed was semi-open, meaning that the teacher was given the opportunity to answer the questions asked with a short description. 
Table 6. Result of Questionnaire to teachers

\begin{tabular}{|c|l|l|}
\hline No & \multicolumn{1}{|c|}{ Statement/question } & \multicolumn{1}{|c|}{ Answers/Reasons/Descriptions } \\
\hline 1 & $\begin{array}{l}\text { Are there any difficulties using the } \\
\text { game during learning? }\end{array}$ & $\begin{array}{l}\text { No, because there are printed instructions on how to use it, } \\
\text { and teachings were carried out before playing the game. } \\
\text { No, however, the teacher needs to study before using it in } \\
\text { class. }\end{array}$ \\
\hline 2 & $\begin{array}{l}\text { It was a playful atmosphere, even though the process of } \\
\text { learning was also being conducted. } \\
\text { Students are motivated to personally discover information } \\
\text { using the game, with curiosity for the next material. } \\
\text { It prevents students from visiting the game center because } \\
\text { several of the games are not educative. }\end{array}$ \\
\hline 3 & $\begin{array}{l}\text { How does the learning plan support } \\
\text { the implementation of using games } \\
\text { as a learning media? }\end{array}$ & $\begin{array}{l}\text { Good, it needs to be continued and aids the learning process. } \\
\text { Learning tools aid the implementation of learning. }\end{array}$ \\
\hline 4 & $\begin{array}{l}\text { Do you desire to continue using } \\
\text { games as a learning media? }\end{array}$ & $\begin{array}{l}\text { Yes, it is necessary because it has motivated the students to } \\
\text { become eager to learn. } \\
\text { I agree because the pleasure students derive from playing } \\
\text { games is now channeled to the class. } \\
\text { I strongly agree that the teacher needs to get involved in the } \\
\text { training to create a new atmosphere in the classroom and } \\
\text { trigger creativity. }\end{array}$ \\
\hline
\end{tabular}

The results from the questionnaire showed that the teachers did not encounter any difficulty while using the game. It meant that computer-based games could be used as learning media because it described atomic materials in detail. The teacher stated that the use of games media needed to be continued due to it created new insight and atmosphere, as well as stimulated the creativity of both the teacher and students. The teacher reported that the students were motivated to personally discover information using the game and curios for the next material. The teacher also stated that the employment of games as a learning media was very good because it could be used as alternative for playing, and hopefully it could prevent students from playing noneducational games outside the school premises. According to teacher's observation, the types of games in game centers and on the internet tend to cause violent attitudes and ethics that are not appropriate for the age of students and Indonesian culture.

The teachers hoped that the use of games could be continued and developed for other science topics and other grade levels, such as class VII and VIII. The results from this questionnaire supports that the use of games as a learning media attracts the attention of students [19]. Therefore, it motivates and creates more varied learning methods, resulting in students participate more in academic activities [7]. The teachers found that it had advantage that learning is carried out according to plan.

\subsection{Teacher interview}

Interviews were conducted to teachers to obtain additional information concerning the implementation of using games to study science and clarification of the teachers' 
answers in the questionnaire. The main points and results from the interview are shown in Table 7.

Table 7. Teacher interview results

\begin{tabular}{|c|l|l|}
\hline No & \multicolumn{1}{|c|}{ Main interview } & \multicolumn{1}{|c|}{ The main of the teacher's answer } \\
\hline 1 & $\begin{array}{l}\text { The teacher's response to the comfort of } \\
\text { using the game as a science learning } \\
\text { media. }\end{array}$ & $\begin{array}{l}\text { The Teachers, principal, and parents support the idea. This } \\
\text { is proven by the fact that parents allow their children to } \\
\text { bring laptops to class while schools lend to those that do } \\
\text { not have. }\end{array}$ \\
\hline 2 & $\begin{array}{l}\text { The role of learning tools in motivating } \\
\text { students. }\end{array}$ & $\begin{array}{l}\text { It helps during learning, particularly when discussing in } \\
\text { groups after playing. Student worksheets direct the learning } \\
\text { objectives that need to be achieved. }\end{array}$ \\
\hline 3 & $\begin{array}{l}\text { Teacher expectations from the use of } \\
\text { games as a learning media to study } \\
\text { science. }\end{array}$ & $\begin{array}{l}\text { Interesting, although at the same time, it is challenging for } \\
\text { the science teacher because it needs to discover other } \\
\text { games and learn it first. In addition, support facilities such } \\
\text { as electricity networks and laptop/computer availability are } \\
\text { necessary and need to be provided. }\end{array}$ \\
\hline
\end{tabular}

The teachers were interviewed after the lesson, they reported that students were enthusiastic when it was announced that they would be using computers during science learning. Head of the two schools also supported the use of ICT or computers due to the science laboratory facilities were still limited. The teacher required the use of computer games during learning process and was willing to try it on other science topics. Learning instruments such as Student Worksheets and Teaching Materials also helped with the implementation of learning. The results from this interview showed that learning instrument as support tended to help learning process, particularly during discussion. This showed that game media was interpreted as a competition between interacting players by following certain rules to achieve certain goals [12]. A good way to foster interest in learning is through games [16]. The teacher stated that they need to learn the use of game as learning media before implementation because it was novel for them and required time.

\subsection{Student interview}

Interviews were conducted to clarify students' answers in the questionnaire. Ten students from each class were interviewed at the end of the learning process. As many as $90 \%$ of the students responded that they were aware of how to play the game while only one person answered that it was rather difficult. It was discovered that the computers used by the student had issues thus they shared one with their friend. The students were mostly excited with this process, however there were various other reasons, for example, very good, happy, due to excitement, and not boring. Variations in learning made it easy to understand through entertainment. The students interviewed generally said that they did not want to stop using games to learn science, this was in accordance with other answers such as no, let's continue using games, do not want to stop using it because it is interesting to use, do not agree, and do not want to stop. Furthermore, a student requested that other lessons also need to apply this method. The results of this interview strongly supported student questionnaires, in 
which they disagreed with the idea to stop this type of learning process. The results from this interview were in accordance with the principles and characteristics that needed be considered in developing games as learning media including active learning, provides challenges, achieve goals, motivate, and obtain feedback [10].

\subsection{Student learning outcomes}

Learning outcomes of students after implementation of media is presented in Table 8. Average scores of the two classes from the pretest and posttest were found to be increased, with classical completeness at the end of the learning process used to achieve their target. This means based on the completeness level of the two classes, the target was successfully fulfilled, which were $84.30 \%$ and $84.36 \%$ (higher than $75 \%$ ). Then paired t-test was performed to determine the significant differences in the pretest and posttest scores.

Table 8. Student learning outcomes scores in class A and B

\begin{tabular}{|l|c|c|c|c|c|}
\hline Group & $\begin{array}{c}\text { Number of } \\
\text { students }\end{array}$ & $\begin{array}{c}\text { The average of } \\
\text { pretest }\end{array}$ & $\begin{array}{c}\text { The average of } \\
\text { posttest }\end{array}$ & $\begin{array}{c}\text { Pretest } \\
\text { Completeness }\end{array}$ & $\begin{array}{c}\text { Posttest } \\
\text { Completeness }\end{array}$ \\
\hline Class A & 32 & 50.56 & 81.88 & $0 \%$ & $84.30 \%$ \\
\hline Class B & 33 & 44.09 & 83.36 & $0 \%$ & $84.36 \%$ \\
\hline
\end{tabular}

Based statistical tests of pretest and posttest, there was significant difference between pretest and posttest scores achieved by students of both classes ( $p>0.05)$. This indicated that learning atom materials using games was succeeded in improving students' outcomes. This showed that games have the potential to increase students' learning interest, motivation, ability to remember, and think at a higher level. Computer-based games can increase the cognitive learning processes of students and enable them to contributions towards the completing of their tasks [6,22]. Games are not only made for entertainment; but they also have the potential to increase learning success [13]. According to teachers' response, the use of games facilitated students' interest in learning and increases their responses in science learning.

The results of this study are in line with Jones [11], which reported that education utilizes the construction of reward and learning relationships. Specifically, the potential for reward is clearly to increase motivation, and help teachers to influence the process and learning outcomes. Gadgets and games have a positive impact on the world of education [22-27]. Students' completeness also supports this in accordance with the observation results of their activities and implementation of a learning plan prepared by the teacher. Teachers achieve learning targets through the preparation and implementation of plans, as well as the positive response of students during the teaching process. 


\section{Conclusion}

Based on data, analysis results, and discussion, following conclusion can be decided. The teacher believed that the use of computerized games as science learning media was very effective due to its ability to increase students learning activities, thereby fulfilling the target of classical completeness. Teachers needed to have a thorough understanding of ways to operate the game on the computer to improve science learning. The use of games as a science learning media is a solution for students to play and learn at the same time. It also prevents them from indulging in uneducated games commonly found outside schools. The teacher also felt that using games helps in the implementation of learning according to plan. Computer game as science learning media is a challenge that needs to be faced to achieve learning success. The results of the student assessment showed that $80.00 \%$ to $100 \%$ supported the use of computer games as science learning media. Based on statistical test, significant difference was found between the pretest and posttest scores. The limitation of this study was the availability of games that can be used as a science learning media. The continuous development of computer games as a learning media for science is necessary. Games installed in computers or smartphones act as a solution to overcome the boredom experienced by students while studying at home for a long time, such as more than one month. Currently, due to the coronavirus outbreaks in various countries, including Indonesia, students have been asked to study at home using online with teachers or independently.

\section{Acknowledgement}

The authors thanked the school principals, science teachers, and students that provided the resources needed to carry out this research. The authors also thanked Surabaya State University - Indonesia for funding given to this research which enabled completion of this research.

\section{$6 \quad$ References}

[1] Alomari, I., Al-Samarraie, H., \& Yousef, R. (2019). The Role of Gamification Techniques in Promoting Student Learning: A Review and Synthesis. Journal of Information Technology Education, 18, 389-417. https://doi.org/10.28945/4417

[2] Buckley, P., \& Doyle, E. (2016). Gamification and student motivation. Interactive Learning Environments, 24 (6), 1162-1175. https://doi.org/10.1080/10494820. 2014.964263

[3] Becker, N., Stanford, C., Towns, M., \& Cole, R. (2015). Translating across macroscopic, submicroscopic, and symbolic levels: the role of instructor facilitation in an inquiryoriented physical chemistry class. Chemistry Education Research and Practice, 16(4), 769785. https://doi.org/10.1039/c5rp00064e 
[4] Bodily, R., Leary, H., \& West, R. E. (2019). Research trends in instructional design and technology journals. British Journal of Educational Technology, 50(1), 64-79. https://doi.org/10.1111/bjet.12712

[5] Cheng, M.-T., Lin, Y.-W., She, H. C., \& Kuo, P. C. (2016). Is immersion of any value? Whether, and to what extent, game immersion experience during serious gaming effects science learning. British Journal of Educational Technology, 48(2), 246- 263. https://doi.org/10.1111/bjet.12386

[6] Chuang, T.-Y., \& Chen, W.-F. (2009). Effect of Computer-Based Video Games on Children: An Experimental Study. Educational Technology \& Society, 12 (2), 1-10.

[7] Huang, Y.-M. (2019). Exploring students' acceptance of educational computer games from the perspective of learning strategy. Australasian Journal of Educational Technology, 35(3): 132-149. https://doi.org/10.14742/ajet.3330

[8] Davis, K., Sridharan, H., Koepke, L., Singh, S., \& Boiko, R. (2018). Learning and engagement in a gamified course: Investigating the effects of student characteristics. Journal of Computer Assisted Learning, 34(5), 492503. https://doi.org/10.1111/ jcal. 12254

[9] Dewi, M. R. and Lutfi, A. (2014). Development of Game-Based Computer as Learning Media on Atoms, Ions, And Molecules Matter. UNESA Journal of Chemical Education. 3(2), 141-150.

[10] Freitas, S. de. (2010). A Game-based Learning Framework: Linking Game Design and Learning Outcomes. (online). http://sgi.cueltd.net/ publications/papers /Chapter Staald uinen_Freitas -_Final.pdf.

[11] Jones, Paul Howard. (2011). Toward a Science of Learning Games. Journal Compilation International Mind, Brain, and Education Society and Blackwell Publishing. 5(1).

[12] Kuo, M.-S., \& Chuang, T.-Y. (2016). How gamification motivates visits and engagement for online academic dissemination - An empirical study. Computers in Human Behavior, 55, 16-27. https://doi.org/10.1016/j.chb.2015.08.025

[13] Lutfi, A., Suyono, Erman, and Aftinia, F. (2017). The Quality of Natural Science Instruction Using Games as Computer-Based Instructional Media. Proceeding. The 1st Mathematics, Informatics, Science, And Education International Conference (MISEIC) "Building Togetherness for The Upcoming Challenges in Mathematics, Informatics, Science, and Education" in Surabaya, 9 September 2017, ISBN: 978-602-449-116-1. p 402 - 408 https://doi.org/10.2991/miseic-19.2019.45

[14] Lutfi, A. (2013). Motivate Students to Learn Science by Implementing Bilingual Comic Learning Media. Journal of Education and Learning. 20(2), 152-159.

[15] Meier, Dave. (2002). The Accelerate Learning Handbook. Penerjemah Rahmani Astuti. Bandung: PT Mizan Pustaka.

[16] Nur, M. (2008). Motivating Students to Learn. Surabaya: UNIPRESS.

[17] Park, Hyungsung. (2012). Relationship between Motivation and Student's Activity on Educational Game. International Journal of Grid and Distributed Computing. 5 (1).

[18] Rosyid, Harits. Ar., Palmerlee, Matt., and Chen, Ke. (2018). Deploying learning materials to game content for serious education game development: A case study. Entertainment Computing, 26, 1-9. https://doi.org/10.1016/j.entcom.2018.01.001

[19] Smaldino, S. E., Lowther, D. L., and Clif, M. (2019). Instructional Technology and Media for Learning 12th Edition. United States of America: Pearson Education.

[20] Kalogiannakis, M., Nirgianaki, G.-M., \& Papadakis, St. (2018). Teaching magnetism to preschool children: the effectiveness of picture story reading. Early Childhood Education Journal, 46(5), 535-546. https://doi.org/10.1007/s10643-017-0884-4

[21] Supardi. (2017). Educational Research Statistics. Depok: Rajawali Pers. 
[22] Alhalafawy, W. S., and Zaki, M. Z. T. (2019). The Effect of Mobile Digital Content Applications Based on Gamification in the Development of Psychological Well-Being. International Journal of Interactive Mobile Technologies, 13(8). https://doi.org/10. 3991/ijim.v13i08.10725

[23] Yunita, A., Nurse chafia, Setiawan, E., \& Nugroho, H. (2018). The Relationship between Mobile Phone Usage in Classroom and Academic Achievement in College Life. International Journal of Interactive Mobile Technologies: 12(8), 96-103. https://doi.org/10. 3991/ijim.v12i8.9530

[24] Fawareh, H.M.A. \& Jusoh, S. (2017). The Use and Effects of Smartphones in Higher Education. International Journal of Interactive Mobile Technologies: 11(6), 103-111.

[25] Kalogiannakis, M., \& Papadakis, S. (2019). Evaluating pre-service kindergarten teachers' intention to adopt and use tablets into teaching practice for natural sciences. International Journal of Mobile Learning and Organization, 13(1), 113-127. https://doi.org/10. 1504/ijmlo.2019.10016617

[26] Papadakis, S. (2018). Evaluating pre-service teachers' acceptance of mobile devices with regards to their age and gender: a case study in Greece. International Journal of Mobile Learning and Organization, 12(4), 336-352. https://doi.org/10.1504/ijmlo.2018. $\underline{10013372}$

[27] Papadakis, S. (2020). Evaluating a game-development approach to teach introductory programming concepts in secondary education. International Journal of Technology Enhanced Learning, 12(2), 127-145. https://doi.org/10.1504/ijtel.2020.106282

\section{$7 \quad$ Authors}

Dr. Achmad Lutfi, M.Pd. is an Assistant Professor of Chemistry Education at the Faculty of Mathematics and Natural Sciences and Postgraduate at Universitas Negeri Surabaya, Indonesia. He is also a member of the Indonesian Chemical Society (HKI), and an instructor in teaching media using games. Email: achmadlutfi@unesa.ac.id

Rusly Hidayah, S.Si., M.Pd. is a member of the Indonesian Chemical Society (HKI), and a lecturer in the Chemistry Education Study Program at the Faculty of Mathematics and Natural Sciences at Universitas Negeri Surabaya - Indonesia.

Article submitted 2020-04-23. Resubmitted 2020-10-14. Final acceptance 2020-10-14. Final version published as submitted by the authors. 